\title{
INNOVATION SYSTEM OF TAMPERE REGION AS AN EXAMPLE OF GOOD PRACTICE FOR THE SOUTH MORAVIAN REGION
}

\author{
[Inovační systém regionu Tampere jako př́iklad dobré praxe pro Jihomoravský \\ kraj]
}

\author{
Šárka Fránková ${ }^{1}$, Kateřina Gašová ${ }^{2}$ \\ ${ }^{1}$ Masarykova univerzita, Ekonomicko-správní fakulta, Lipová 41 a, 60200 Brno \\ Email:frankova.sarka@mail.muni.cz \\ ${ }^{2}$ Masarykova univerzita, Ekonomicko-správní fakulta, Lipová 41a, 60200 Brno \\ Email:349174@mail.muni.cz.
}

\begin{abstract}
Research, development and innovation is considered to be a main driver of economic development. Innovation policy becomes therefore one of the most important public policies. There exists general agreement that the best way to support innovation is to aim at the regional level while realizing innovation policy. Proximity enables regional actors to create tacit knowledge ensuring powerful competitive advantages for both firms and regions. At the same time, the concept of regional innovation systems is the most promising way to support innovation and knowledge transfer in the region. The paper presents the case of Tampere innovation system as an example of good practice for the South Moravian Region. Although it is only possible to learn limitedly from other regions it the case of innovation policy (because of regional specifics), an analysis of Tampere innovation system can provide useful information. The paper argues that the most important strength of Tampere innovation system is an intensive cooperation between actors of innovation process based on longlasting trust.
\end{abstract}

Keywords: good practice, innovation policy, instrument mix, regional innovation system, regional development, South Moravian Region, Tampere.

JEL classification: H2, H710, M2, R1, R5

Doručeno redakci: 18.1.2016; Recenzováno: 2.2.2015; 4.3.2015; Schváleno k publikování: 26.5.2016

\section{Úvod}

V dnešním globalizovaném světě hledají odborníci na akademické i praktické úrovni nové a nové způsoby, jak dosáhnout ekonomického růstu států a regionů. V poslední době se jejich pozornost stále častěji upírá $\mathrm{k}$ výzkumu, vývoji a inovacím. Tvorba znalostí a neustálé zavádění inovací je nejlepším způsobem, jakým mohou firmy $\mathrm{v}$ regionu dosáhnout konkurenčních výhod na trhu.

Podpora výzkumu, vývoje a inovací se tak stává jednou z nejdůležitějších politik národních a regionálních vlád. S realizací inovační politiky se však pojí značná dávka nejistoty. Jen stě̌̌í je totiž možné předvídat její přesné dopady a zároveň je zcela jisté, že se tyto dopady budou lišit např́ič jednotlivými regiony, protože každý region má svá specifika. Mohlo by se tak snadno stát, že podnět, který vyspělým průmyslovým oblastem výrazně napomůže $\mathrm{k}$ rozvoji, zároveň vytvoří slabším periferním oblastem další rozvojové bariéry. Jaký tedy zvolit přístup $\mathrm{k}$ inovační politice a její implementaci?

Při hledání nejefektivnějších způsobů realizace inovační politiky byl vytvořen koncept regionálních inovačních systémů (Cooke a kol., 1997, Asheim a Isaksen, 2002, Metcalfe a Ramlogan, 2008) který klade důraz na propojení jednotlivých aktérů působících v inovačním procesu a jejich vzájemnou spolupráci a učení (Lundvall a kol., 2002, Doloreux, 
2002). V rámci tohoto konceptu spočívá role veřejné politiky v nastavení takových podmínek, ve kterých jsou aktéři motivováni k vzájemné spolupráci a ke sdílení znalostí. Dle Doloreuxe (2002) by měl být inovační systém tvořen čtyřmi základními prvky, a to firmami, institucemi, znalostní infrastrukturou a politikami podpory inovací. Významnou roli potom v inovačním systému hraje faktor blízkosti (Boschma, 2005, Rallet a Torre, 2005, Drahošová a Bednár̆, 2014). Vzájemná prostorová, ale i kulturní a sociální blízkost zvyšuje důvěru mezi aktéry a tím i pravděpodobnost jejich spolupráce (Doloreux, 2002, Ludnvall a kol., 2002).

Problémy s odlišným dopadem inovační politiky napříč územími a důležitost faktoru blízkosti aktérů inovačního procesu potom společně tvoří hlavní argument pro tvrzení, že pro realizaci inovační politiky je ideální regionální úroveň (Howells, 2005; Tödtling a Trippl, 2005; Flanagan a kol, 2011; McCann a Ortega-Argilés, 2013). Přri takovém přístupu jsou na státní úrovni pouze nastaveny rámcové podmínky, cíle a vize pro inovační politiku, avšak konkrétní postupy v podpoře výzkumu, vývoje a inovací vznikají na úrovni regionů dle jejich specifických potřeb.

V souvislosti s inovační politikou a regionálním inovačním systémem je často uváděn pojem politický mix (Flanagan a kol., 2011, Uyarra, 2010, Smits a Kuhlmann, 2004). Tento pojem představuje souhrn nástrojů podpory výzkumu, vývoje a inovací speciálně sestavený „na míru“ danému území. Nástroje, které jsou do mixu zahrnuty, by měly mít smysluplná teoretická odůvodnění, zároveň by však měly reagovat na aktuální potřeby regionu (Flanagan a kol., 2011). Tvorbě mixu je třeba věnovat velkou pozornost a neuspěchat celý proces, jelikož účinky některých nástrojů se projeví až po značném časovém prodlení. Proto by špatně zvolené politické nástroje mohly mít dlouhodobě negativní dopad na region. Pečlivé zhodnocení aktuálního stavu regionu, definování klíčových oblastí podpory a pojmenování hlavních problémů zde má svůj nepochybný význam (Borrás a Edquist, 2013). Falagan a kol. (2011) dále zdůrazňují, že do procesu tvorby politického mixu by měli být zahrnuti všichni aktéři inovačního procesu v regionu a že je zcela nemožné, aby kvalitní politický mix vznikl direktivně pouze $z$ nejvyšší politické úrovně.

Možných nástrojů užívaných pro podporu inovací je velké množství a je často velmi obtížné se $\mathrm{v}$ takovémto množství zorientovat. Proto jsou nástroje podle nejrůznějších charakteristik členěny do skupin a kategorií. Jako prríklad jednoho z možných členění může být uvedeno rozdělení nástrojů na regulační, ekonomické a měkké nástroje dle Borráse a Edquista (2013). Mezi regulační nástroje patří zákony, závazná pravidla či právní nařízení a jejich účelem je určování „pravidel hry“. Mezi ekonomické nástroje jsou zařazeny takové nástroje, které vytváří ekonomické podněty a stimuly pro inovační chování firem. Jsou to tedy veškeré druhy finanční a materiální podpory, daňová zvýhodnění a další. Soft nástroje jsou charakteristické tím, že jsou založeny na principu dobrovolnosti. Mají spíše charakter přesvědčování aktérů o tom, že je vzájemná spolupráce oboustranně prospěšná.

Dalším možným členěním inovačních nástrojů může být jejich rozdělení na přímé a nepřímé. Zatímco prímé nástroje zahrnují konkrétní stimuly, jejichž výstupem je inovovaný produkt, proces nebo služba, nepř́mé nástroje jsou obecnější a spíše celkově vylepšují ekonomické prostředí tak, aby v něm mohl vzniknout kvalitní inovační systém (Gašová, 2015).

Otázkou, jaké konkrétní nástroje podpory inovací zvolit, se zabývají mnozí autoři (McCann a Ortega-Argilés, 2013, Tödtling a Trippl, 2005, Asheim a Nauwelaers, 2003, Laranja a kol., 2008), avšak dá se říci, že jednoznačná odpověd' na ni neexistuje. $Z$ důvodu regionálních specifik nelze využít prŕístupu jediného modelu aplikovatelného na všechny regiony (tzv. one- 
size-fits-all př́stup) a $z$ dobré praxe úspěšných inovátorů je možné se poučit pouze částečně (se zohledněním toho, že podmínky v každém regionu jsou specifické). Někteří autoři však na základě případových studií vytvořili doporučení vhodných politických mixů pro různé typy regionů. Takto např́íklad McCann a Ortega-Argilés (2013) navrhují konkrétní nástroje podle úrovně vyspělosti a podle zaměření regionu a Tödtling a Trippl (2005) navrhují nástrojové mixy speciálně pro problémové regiony.

Předkládaný př́íspěvek věnující se finskému regionu Tampere je případovou studií dobré praxe v budování a rozvoji regionálního inovačního systému. Cílem př́spěvku je analyzovat tento inovační systém a odhalit stěžejní prvky a silné stránky, které přivedly region Tampere do jeho současné pozice evropského inovačního leadera. Zjištěné skutečnosti mohou být využitelné pro Jihomoravský kraj, který jeden ze svých strategických cílů zaměřil na dosažení srovnatelné pozice s evropskými inovačními centry, jako je Tampere (Chládek, 2014). Př́spěvek tedy hledá odpověd' na otázku, jakou cestou by se měl Jihomoravský kraj ubírat, pokud chce dosáhnout podobných výsledků jako region Tampere. Struktura př́spěvku je následující: první část popisuje vývoj regionu Tampere do jeho současného stavu, druhá část analyzuje inovační systém regionu, třetí část předkládá nástrojový mix regionu Tampere jako př́klad dobré praxe pro Jihomoravský kraj a čtvrtá část shrnuje perspektivy Jihomoravského kraje do budoucna.

\section{Region Tampere a jeho cesta do pozice inovačního leadera}

Provincie Pirkanmaa je s počtem obyvatel okolo 500 tisíc druhým největším regionem Finska. Jejím střediskem je město Tampere, podle kterého je často celý region nazýván regionem Tampere (Tampere Region, 2015ä). Provincie se nachází v západní části Finska a od hlavního města, Helsinek, je Tampere vzdáleno asi $180 \mathrm{~km}$. Dle Schienstocka a kol. (2004) hrál tento region vždy významnou roli ve finské ekonomice a město Tampere, druhé nejvýznamnější centrum Finska po Helsinkách, je lokálně známé jako „Finský Manchester“.

Na počátku devadesátých let bylo celé Finsko silně zasaženo hospodářskou krizí a brzy bylo zřejmé, že dosud prosperující tradiční průmysl založený na zpracování př́rodních zdrojů nebude cestou, která jej z krize vyvede. Proto došlo ke všeobecné shodě v tom, že je třeba vytvořit zcela nový rozvojový směr postavený na znalostních odvětvích. Finsko, které bylo dosud silně centralizovanou zemí, začalo vytvářet podmínky pro rozvoj výzkumu, vývoje a inovací, s čímž souvisela také regionalizace (Schienstock a kol., 2004).

Region Tampere je často uváděn jako prríklad regionu, který byl schopen vymanit se z tzv. „path dependency“ neboli závislosti na zvolené cestě. Regiony zasažené tímto problémem jsou většinou úzce specializovány a je pro ně velmi problematické změnit své zaměření ve chvíli, kdy jejich specializace přestane vést k prosperitě (Hassink, 2005, Fuchs a Shapira, 2005). Během hospodářské krize čelila právě tomuto problému finská ekonomika.

Region Tampere byl před hospodářskou krizí $\mathrm{v}$ devadesátých letech prosperujícím průmyslovým regionem zaměřujícím se především na potravinářský a chemický průmysl. Př́chod krize však byl pro region, stejně jako pro celou zemi, bodem zlomu. Novým strategickým cílem se stalo založení high-tech oborů spolu s modernizací tradičních odvětví (Kolehmainen, 2002). Proces deindustrializace, který byl ve Finsku př́ichodem krize zahájen, se sice $\mathrm{v}$ Tampere začal projevovat poměrně pozdě ve srovnání $\mathrm{s}$ dalšími regiony, avšak jelikož již v té době hrál významnou roli také sektor ICT (právě do tohoto sektoru směřovala celá polovina prostředků na výzkum a vývoj), byla následná přeměna ekonomické struktury neobyčejně rychlá a region Tampere se stal, dá se říci, ICT velmocí (Schienstock a kol., 
2004). Obrázek 1 ukazuje, jak se v regionu Tampere v období mezi lety 1995 - 2014 vyvíjela výše investic do výzkumu a vývoje. Patrný výrazný nárůst potvrzuje zaměření regionu na tento sektor.

Obrázek 1: Vývoj investic do výzkumu a vývoje v regionu Tampere (mil. EUR)

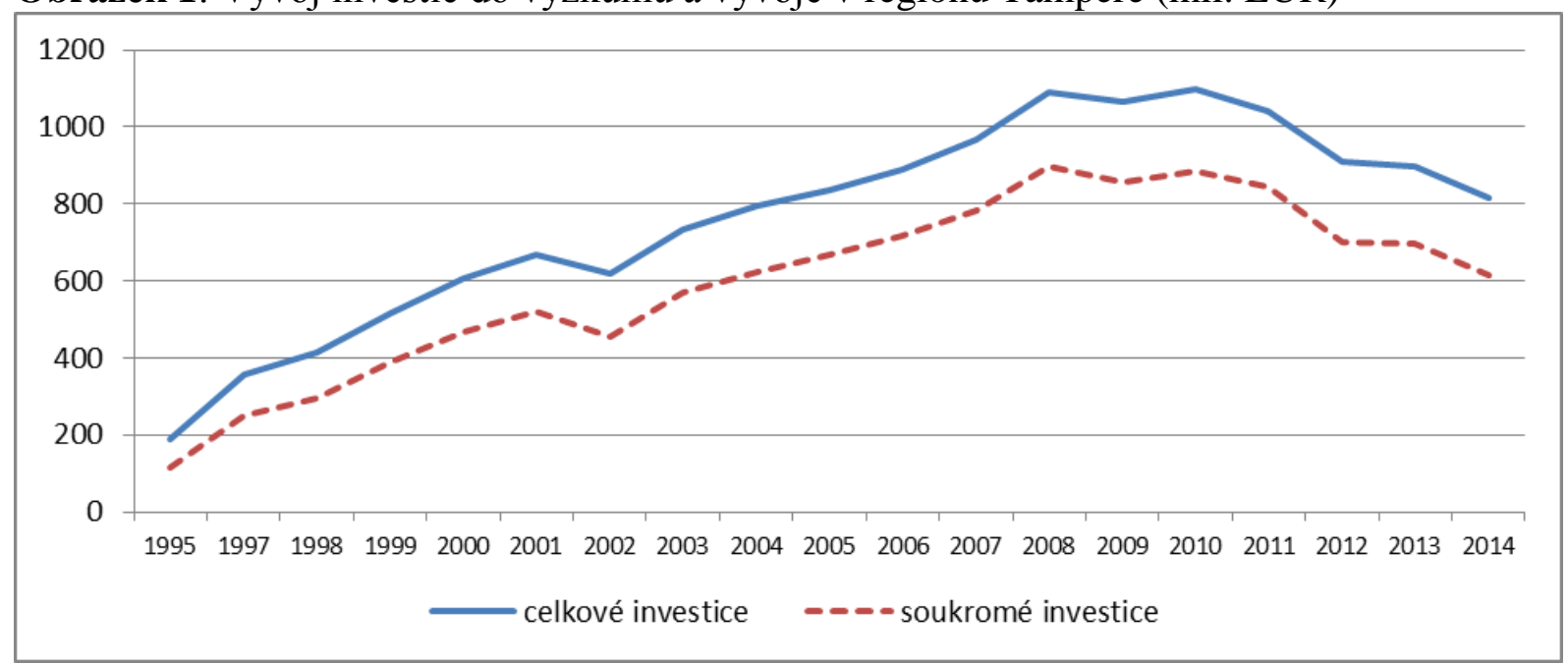

Zdroj: Statistics Finland (2015)

Nyní region disponuje diverzifikovanou ekonomickou strukturou založenou na specializovaných klastrech. Nejvíce zastoupenými průmyslovými odvětvími jsou technologický průmysl, informační a komunikační technologie, lesnictví, chemický průmysl, potravinářský průmysl a textilní průmysl. Jejich zastoupení je dále konkretizováno v kapitole 2.2. Firmy fungující $\mathrm{v}$ těchto klastrech jsou podporovány univerzitami, výzkumnými institucemi a technologickými centry, stejně jako místní veřejnou správu (Kolehmainen, 2002). Několik výzkumů provedených v Tampere (např. Kautonen, 2006, Yigitcanlar a kol., 2014) potvrzuje, že mezi největší přednosti regionu patří vysoce kvalifikovaná pracovní síla a také neobyčejná schopnost místních firem přeměnit se v učící se organizace, vytvářet kvalitní produkty a flexibilně se přizpůsobovat změnám.

Dle hodnocení Evropské komise Regional Innovation Scoreboard patř́i Západní Finsko spolu s regionem Tampere k inovačním leaderům. V roce 2013 vynaložilo na výzkum a vývoj 3,98 \% HDP, čímž mírně presahuje státní podíl $(3,31 \%)$ a výrazně $(2,01 \%)$ podíl evropský (Regional Innovation Monitor Plus, 2015, Eurostat, 2015). Západní Finsko disponuje vysokou patentovou aktivitou a právě v regionu Pirkanmaa v okolí města Tampere jsou výzkumné a vývojové aktivity nejvíce koncentrovány (Regional Innovation Monitor Plus, 2015).

\section{Inovační systém regionu Tampere}

Jak bylo uvedeno výše, fungující inovační systém by se měl skládat z inovativních firem, ze znalostní infrastruktury a výzkumných institucí a univerzit, přičemž by měl být doplňován a rozvíjen nástroji veřejné správy. Pro inovační proces je stěžejní, aby byla vyvážena strana nabídky znalostí a strana poptávky po nich, kdy nabídku zajišt’ují zejména výzkumné instituce a univerzity a poptávku především inovační firmy. V ideálním př́ípadě by obě strany měly být motivovány k vzájemné spolupráci.

\subsection{Nabídka znalostí}

Jednou z největších předností regionu je vysoce kvalifikovaná pracovní síla. Vysokoškolské vzdělání je př́mo ve městě Tampere poskytováno na třech univerzitách: Tampere University of Technology, University of Tampere a Tampere University of Applied Sciences. Dále 
v regionu působí výzkumná pracoviště, z nichž nejvýznamnějším je Technical Research Centre of Finland.

Tampere University of Technology (TUT) je univerzita, která vždy byla a stále je klíčovým hráčem v inovačním systému regionu. Univerzita byla jmenována Centrem excelence ve výzkumu v oboru polovodičů, hydrauliky, zpracování digitálního signálu a automatizace a poskytuje špičkové technické vzdělání. TUT má v regionu dlouholetou tradici a aktivně spolupracuje s místními průmyslovými firmami. Tato spolupráce probíhá jednak výměnou pracovní síly mezi univerzitou a firmami, dále prostřednictvím závěrečných prací studentů, které jsou zpracovávány ve spolupráci s místními firmami, a v neposlední řadě nejrůznějšími školeními a kurzy, které univerzitní pracovníci poskytují firmám. Univerzita také nabízí odborníkům z místních firem možnost částečně se podílet na výuce.

Univerzita nabízí pět doktorských studijních oborů a speciální možnost získat doktorát při zaměstnání v oblasti výzkumu a vývoje (Tampere University of Technology, 2015). Asi $60 \%$ výzkumu, který na univerzitě probíhá, je financován externě právě průmyslovými firmami, které si objednávají výzkum a vývoj na zakázku (Tampere University of Technology, 2015, Schienstock a kol., 2004).

University of Tampere (UTA) značně posílila svůj význam v devadesátých letech, kdy začal region aktivně pracovat na budování svého inovačního systému. Tato univerzita má tradici v humanitních vědách a oborech veřejného sektoru, její lékařská fakulta však s firmami v regionu aktivně a dlouhodobě spolupracovala již před př́íchodem ekonomické krize. V devadesátých letech se zde rozvinul obor výpočetní techniky a informatiky, což byl hlavní důvod pro vznik Fakulty informačních věd v roce 2001 (University of Tampere, 2015, Schienstock a kol., 2004). Univerzita nabízí celkem devět oblastí doktorského studia, které se dále člení na jednotlivé obory.

Tampere University of Applied Scieces je nedávno založená univerzita zaměřující na oblast aplikovaných věd, která zároveň provozuje vlastní výzkum a vývoj v této oblasti. (Tampere University of Applied Sciences, 2015).

Vedle univerzitních výzkumných kapacit disponuje region také specializovanými výzkumnými pracovišti, tím nejvýznamnějším je VTT.

VTT Technical Research Centre of Finland je hlavní výzkumné centrum ve Finsku, které má v Tampere jednu ze svých čtyř poboček. Zde zaměstnává asi 250 pracovníků (Kautonen, 2006; VTT, 2015). VTT má tři hlavní oblasti výzkumu, a to znalostně intenzivní produkty a služby, smart průmysl a energetické systémy a řešení pro př́rodní zdroje a životní prostředí. Výzkumné centrum bylo založeno v roce 1942 pod záštitou finského Ministerstva průmyslu a obchodu, a ačkoli bylo nezávislou organizací, velmi těsně z počátku spolupracovalo s univerzitou v Helsinkách. Určitou dobu byla celá společnost plně vlastněna státem, nyní má status společnosti s ručením omezeným, avšak stále přijímá finance na výzkum a vývoj z veřejných zdrojů (VTT, 2015).

\subsection{Poptávka po znalostech}

V Tampere fungují specializované průmyslové aglomerace firem, které jsou z velké části zvyklé na dlouhodobou spolupráci s místními výzkumnými institucemi (Kautonen, 2006) a tvoří tak poptávku po znalostech. Tabulka 1 poskytuje přehled o počtu firem v jednotlivých průmyslových odvětvích a o obratu, který vytvářejí. 
Tabulka 1: Průmyslových odvětví v regionu Tampere

\begin{tabular}{|l|c|c|}
\hline \multicolumn{1}{|c|}{ průmyslové odvětví } & počet firem (2015) & obrat (mil. EUR, 2014) \\
\hline technologický průmysl & 976 & 4434 \\
\hline lesnictví & 423 & 2364 \\
\hline chemický průmysl & 143 & 1608 \\
\hline informační a komunikační služby & 1109 & 1272 \\
\hline potravinářský průmys & 139 & 591 \\
\hline textilní průmysl & 139 & 270 \\
\hline
\end{tabular}

Zdroj: Tampere Chamber of Commerce and Industry (2015)

Pokud se zaměříme na odvětví výzkumu a vývoje, je jeho zastoupení v regionu následující (viz. Tabulka 2):

Tabulka 2: Zastoupení odvětví vědeckého výzkumu a vývoje v regionu Tampere

\begin{tabular}{|c|c|c|}
\hline počet firem & celkový počet zaměstnanců & obrat/osoba (mil. EUR) \\
\hline 71 & 469 & 142 \\
\hline
\end{tabular}

Zdroj: Statistic Finland (2015)

Sektor informačních a komunikačních služeb je pochopitelně výrazně ovlivněn nejvýznamnějším zaměstnavatelem v regionu, Nokia Group. Firma Nokia měla díky svému mezinárodnímu významu velký vliv na utváření inovačního systému regionu Tampere i celého Finska. Nokia již dlouhou dobu aktivně spolupracuje s firmami i univerzitami v celé zemi, avšak v regionu Tampere probíhá tato spolupráce nejintenzivněji. Nokia z části utvářela současnou podobu vysokoškolského vzdělávání v regionu svými požadavky na kvalifikaci pracovní síly a zároveň vytvořila celou sít' spolupracujících firem a institucí, mezi které patří její dodavatelé a odběratelé, univerzity i výzkumné laboratoře. V roce 2000 tvořil podíl firmy na národním HDP $4 \%$, avšak v posledním desetiletí se Nokia potýká s problémy z důvodu velkého růstu konkurenčních firem (např. Apple a Android) a její podíl na HDP se do roku 2013 snížil na 0,5 \% (World economic forum, 2015). Dalším negativním jevem posledních let souvisejícím s firmou Nokia je přesun výroby do levnější Asie (Ali-Yrkkö a Hermans 2002).

Vedle pozitiv plynoucích z velkého množství významných inovativních firem, které v regionu sídlí, zde existuje jeden problém. Z tohoto velkého množství má jen velmi málo firem (dle Schienstocka a kol., 2004, pouze dvě firmy ze sta) v regionu své řídící pracoviště. Jelikož nejzásadnější firemní rozhodnutí padají právě v řídících pracovištích, ztěžuje tento fakt práci regionální vládě a mohl by mít negativní důsledky do budoucna.

\subsection{Podpůrné instituce}

Schienstock a kol. (2004) uvádí, že se v poslední době zaměření finské inovační politiky přesouvá od poskytování př́mé podpory v podobě grantů či dotací spíše k povzbuzování vzájemného dialogu aktérů a $\mathrm{k}$ vytváření nových podnětů pro spolupráci. To lze hodnotit velmi pozitivně, jelikož je zřejmé, že inovační systém je již natolik vyspělý, že nepotřebuje prímou podporu, ale pouze podněty $\mathrm{k}$ vytváření dalších vazeb mezi aktéry.

V regionu Tampere existují aktivní instituce, které mají za cíl podporu místního inovačního systému. Tři nejvýznamnější z nich jsou popsány v následujícím textu.

Hermia Group se skládá ze dvou společností, New Factory a Tamlink, a poskytuje široké služby voblasti networkingu. Vlastníky Herma Group jsou Tampere University of 
Technology, město Tampere, Tampere Technological Society a VTT. Prostřednictvím svých služeb propojuje know-how firem, výzkumných institucí a veřejného sektoru především v oblasti strojírenství. Aktivity Hermia Group se zaměřují na (Hermia Group, 2015):

- pomoc začínajícím firmám s vývojem jejich inovativního produktu, přičemž jsou využívány výzkumné kapacity Tampere University of Technology (Confidential R\&D projects)

- sdružování firem a talentovaných studentů za účelem sdílení a realizace inovativních nápadů (Demola)

- spojování firem do skupin, ve kterých spolupracují na výzkumu a vývoji či na řešení konkrétních problémů (Corporate group projects)

- podporu start-upů (Protomo, Accelerator)

- propojování firem ze stejných odvětví a podněty pro tvorbu klastrů (FIMA, Game Factory, ITS Factory)

Finnmedi je mezinárodně fungující společnost, která poskytuje služby spojené s rozvojem podnikání a zároveň provádí výzkum a vývoj v oblasti vědy o živé prŕrodě. Společnost zprostředkovává svým klientům know-how, nabízí jim své vědecké pracovníky a otevírá ji cestu k výzkumným kapacitám univerzit i k rizikovému financování. Díky dlouholetým vazbám a konexím nabízí Finnmedi mladým začínajícím firmám zapojení do sítě spolupracujících subjektů v oboru life science. Společnost je vlastněna veřejným sektorem, přičemž z největší části ji vlastní město Tampere a Pirkanmaa Hospital District (Finnmedi, 2015).

Tampere Regional Economic Development Agency (Tereda) je agentura, která pracuje na zvyšování pravděpodobnosti úspěchu nových inovativních podniků. Poskytuje bezplatné poradenské služby, asistenci při tvorbě podnikatelského záměru. Hlavním cílem agentury je zvyšování atraktivity regionu Tampere v očích investorů, kvalifikovaných pracovníků, inovátorů i turistů. Tereda je vlastněna z největší části městem Tampere, dále potom okolními obcemi (Tereda, 2015).

V regionu mají vliv i národní podpůrné organizace, z nich nejvýznamnější je Finnish Funding Agency for Innovation - TEKES. Agentura řídí mnohé národní programy, jejichž cílem je také rozvoj regionálních inovačních systémů, a podílí se na organizaci regionálních programů. Její aktivity jsou financovány z veřejných zdrojů (Tekes, 2015).

\subsection{Regionální inovační strategie}

Tvorba regionálních inovačních strategií je efektivní způsob, jak docílit systematického úsilí regionů na podpoře jejich inovační výkonnosti. Kvalitně zpracovaná regionální inovační strategie umožňuje průběžně realizovat aktivity vedoucí k naplnění stanovených cílů, které by měly reagovat na zjištěné problémy či rozvojové bariéry regionu. Tvorbě regionální inovační strategie by měla vždy předcházet pečlivá evaluace současného stavu inovačního systému regionu a zjištění potřeb jeho aktérů. Tvorba inovačních strategií je zcela ponechána na regionálních vládách $(\mathrm{OECD}, 2010)$.

Region Tampere v současnosti realizuje regionální inovační strategii, která bude platná do roku 2017. Vizí regionu je stát se nejdynamičtějším inovačním regionem Finska, ve kterém existují specializované vědecké platformy, kvalitní produkční struktury, špičkové lidské zdroje, dynamická veřejná správa, a ve kterém je mezinárodnost pevně usazena do běžného života (Tampere Region Innovation Strategy, 2008). Hlavní body inovační strategie jsou shrnuty v Tabulce 3 . 
Tabulka 3: Základní body inovační strategie regionu Tampere

\begin{tabular}{|c|c|c|}
\hline Problémové oblasti & Strategický cíl & Aktivity \\
\hline $\begin{array}{l}\text { Globalizace a } \\
\text { zvyšující se } \\
\text { konkurence }\end{array}$ & $\begin{array}{l}\text { Posilování a expanze inovací } \\
\text { založených na znalostech }\end{array}$ & $\begin{array}{l}\text { - převzetí rozhodující role v mezinárodních inovačních } \\
\text { institucích } \\
\text { - meziregionální vyjednávání za účelem zakládání } \\
\text { spolupracujících inovačních struktur } \\
\text { - tvorba výzkumných projektů, které kombinují různé } \\
\text { obory } \\
\text { - posilování spolupráce univerzit, firem a veřejné } \\
\text { správy } \\
\text { - zakládání platforem ve stylu „living lab“ } \\
\text { orientovaných na spotřebitele } \\
\text { - podpora multidisciplinární spolupráce aktérů }\end{array}$ \\
\hline $\begin{array}{l}\text { Zvyšující se tlak na } \\
\text { neustálý } \\
\text { technologický vývoj }\end{array}$ & $\begin{array}{l}\text { Rozvoj znalostně } \\
\text { intenzivních služeb }\end{array}$ & $\begin{array}{l}\text { - poskytování profilovaného výzkumu a vývoje } \\
\text { univerzitami a školícími pracovišti } \\
\text { - podpora vzniku firem v oblasti inovativního } \\
\text { poskytování služeb orientovaného na export }\end{array}$ \\
\hline \multirow[t]{2}{*}{ Demografické změny } & $\begin{array}{l}\text { Mezinárodní sítě v podpoře } \\
\text { inovací }\end{array}$ & $\begin{array}{l}\text { - mezinárodní mobilita místních studentů, učitelů a } \\
\text { vědců } \\
\text { - přilákání zahraničních vědců a vzdělaných mladých } \\
\text { lidí do regionu } \\
\text { - tvorba kontaktů se zahraničními a mezinárodními } \\
\text { výzkumnými institucemi a firmami }\end{array}$ \\
\hline & $\begin{array}{l}\text { Rozvoj inovačních } \\
\text { schopností firem }\end{array}$ & $\begin{array}{l}\text { - poskytování špičkových služeb pro inovativní firmy } \\
\text { - podpora transferu technologií a platforem }\end{array}$ \\
\hline
\end{tabular}

Zdroj: vlastní zpracování dle Tampere Region Innovation Strategy (2008)

\section{Nástrojový mix jako př́íklad dobré praxe}

Inovační politika regionu Tampere je velmi aktivní. Tabulka 4 shrnuje nejvýznamnější nástroje, které region zrealizoval či realizuje za účelem podpory inovačního prostředí a ekonomického rozvoje regionu. Dá se říci, že jde o základní stavební kameny nástrojového mixu, které jsou průběžně doplňovány krátkodobými iniciativami.

Z popisu nástrojů lze poznat, že se region ubírá směrem $\mathrm{k}$ co největšímu propojení aktérů působících $\mathrm{v}$ jeho podnikatelském a výzkumném prostředí. Přitom se snaží zapojit nejen aktéry regionální, ale také aktéry z jiných regionů Finska a z jiných zemí. Tuto sít' zapojených subjektů zároveň cíleně posiluje podporou vzniku nových inovativních firem a snahou o maximální využití realizovaného výzkumu a vývoje. Inovační systém regionu již je na špičkové úrovni, důležité je však v této dynamice pokračovat. Proto region usiluje o nové investory a nadějné mladé vědce, pro které se vytváŕí žádoucí image regionu. 
Tabulka 4: Nástrojový mix regionu Tampere

\begin{tabular}{|c|c|c|c|c|}
\hline Název nástroje & $\begin{array}{c}\text { Období } \\
\text { realizace }\end{array}$ & Cíl nástroje & Podstata nástroje & $\begin{array}{c}\text { Zodpovědný } \\
\text { subjekt }\end{array}$ \\
\hline Open Tampere & $2012-2018$ & $\begin{array}{l}\text { Vytvoření mezinárodně } \\
\text { atraktivního prostředí } \\
\text { pro podnikání, vědu a } \\
\text { výzkum }\end{array}$ & $\begin{array}{c}\text { Otevření města } \\
\text { zahraničním fírmám, } \\
\text { studentům, vědcům a } \\
\text { projektům }\end{array}$ & město Tampere \\
\hline $\begin{array}{l}\text { StartUp Tampere } \\
\text { (součást programu } \\
\text { Open Tampere) }\end{array}$ & $2012-2018$ & Podpora Start-upů & $\begin{array}{l}\text { Podpora začínajících } \\
\text { firem formou } \\
\text { rizikového kapitálu či } \\
\text { koučingem }\end{array}$ & město Tampere \\
\hline $\begin{array}{l}\text { Business from } \\
\text { Innovations }\end{array}$ & $2011-2013$ & $\begin{array}{c}\text { Podpora komercializace } \\
\text { inovací }\end{array}$ & $\begin{array}{l}\text { Pomoc malým a } \\
\text { středním podnikům } \\
\text { realizovat inovativní } \\
\text { myšlenky, vzdělávací a } \\
\text { koučingové služby pro } \\
\text { začínající podnikatele }\end{array}$ & Tereda \\
\hline Talent Tampere & nespecifikováno & $\begin{array}{l}\text { Přilákání nadaných } \\
\text { mladých lidí do regionu, } \\
\text { posílení místního } \\
\text { inovačního a } \\
\text { podnikatelského } \\
\text { prostředí }\end{array}$ & $\begin{array}{l}\text { Tvorba sítě spojující } \\
\text { zahraniční talenty a } \\
\text { podniky v regionu, } \\
\text { pomoc se začleněním, } \\
\text { usnadnění prístupu ke } \\
\text { službám, k podnikání a } \\
\text { k výzkumným } \\
\text { kapacitám }\end{array}$ & město Tampere \\
\hline $\begin{array}{l}\text { Centre of Expertise } \\
\text { Programme } \\
\text { (součást celonárodního } \\
\text { programu) }\end{array}$ & $2007-3013$ & $\begin{array}{l}\text { Efektivní využití } \\
\text { odborných znalostí, } \\
\text { podpora meziregionální } \\
\text { spolupráce }\end{array}$ & $\begin{array}{l}\text { Propojení aktérů } \\
\text { působících ve } 13 \\
\text { zapojených finských } \\
\text { klastrech }\end{array}$ & státní instituce \\
\hline $\begin{array}{l}\text { The Innovative Cities } \\
\text { (součást celonárodního } \\
\text { programu s realzací } \\
\text { řízenou na regionální } \\
\text { úrovni) }\end{array}$ & $2014-2020$ & $\begin{array}{c}\text { Podpora vzniku nových } \\
\text { podniků a firem a tím } \\
\text { vzniku nových } \\
\text { pracovních míst }\end{array}$ & $\begin{array}{l}\text { Propojení vládních } \\
\text { orgánů, vzdělávacích } \\
\text { institucí, vědeckých } \\
\text { kapacit a firem s cílem } \\
\text { hledání a vytváření } \\
\text { nových trhů a } \\
\text { podnikatelských } \\
\text { prŕležitostí }\end{array}$ & $\begin{array}{l}\text { státní instituce, } \\
\text { město Tampere }\end{array}$ \\
\hline
\end{tabular}

Zdroj: vlastní zpracování na základě dostupných informací na Regional Innovation Monitor Plus (2015), Tereda (2015)

Na tomto místě není dostatek prostoru pro detailní popis všech uvedených nástrojů. Bude proto popsán nejrozsáhlejší a nejspíše také nejvýznamnější z nich, a to program Open Tampere.

\section{Program Open Tampere $(2012-2018)$}

Tampere spustilo tento program v roce 2012 s cílem vytvořit v regionu mezinárodně atraktivní a na inovacích založené podnikatelské prostředí a upevnit a posílit roli Tampere jako regionu s vysokým standardem a rozvinutým vzdělávacím a výzkumným systémem. Samotný název programu naznačuje, jak by mělo být stanoveného cíle dosaženo - Tampere má být otevřené a umožnit svým obyvatelům zapojovat se do mezinárodních inovačních projektů, pomoci zahraničním studentům najít zaměstnání a poskytnout firmám prostor pro internacionalizaci (Regional Innovation Monitor Plus, 2015). Aktivity programu by tak měly přispívat k vytvoření prostředí, které bude lákavé pro existující i začínající podnikatele z Finska i celého světa. Zároveň by se pro vznik žádoucího podnikatelského prostředí mělo využívat otevřených inovací, spolupráce mezi ekonomickými subjekty a networkingových 
aktivit. Činnosti jsou zaměřeny na následující oblasti: vytváření nových pracovních míst a podniků (především v oblastech, které mají růstový potenciál do budoucna), podporu strukturálních změn v ICT a tradičních odvětvích, vyhledávání investorů rozvojového a rizikového kapitálu a vytváření prostředí, které bude podporovat vznik inovací a inovačních platforem a propagaci atraktivity regionu (především prostřednictvím regionální značky Tampere All Bright!) (Open Tampere, 2015).

Hlavní cílovou skupinou programu jsou začínající podnikatelé, poskytovatelé služeb a podniky s potenciálem růstu. Podstatou programu je však spíše než podpora jednotlivců jejich zapojení do skupin a vytváření partnerství. Existují ještě další cílové skupiny programu, mezi které patří veškeré instituce a subjekty, které ovlivňují vznik inovací, a to jak z veřejného, tak privátního sektoru. Mezi veřejné subjekty, na které program cílí, patří univerzity, výzkumné organizace, vyšší odborné školy a investoři, do skupiny privátních subjektů patř́ místní obyvatelé, komunity a studenti (Open Tampere, 2015).

Základním stavebním kamenem programu Otevřené Tampere je budování a podpora nových nebo existujících takzvaných ,továren na inovace“ (innovation factories). Tato místa představují prostředí a komunity, které umožňují rychlé šśření inovací mezi různými podnikateli a subjekty; výsledkem může být i zakládání nových podniků. V rámci programu již vznikly tři „továrny na inovace“: New Factory, Konela a Mediapolis (Open Tampere, 2015).

New Factory funguje jako podnikatelský inkubátor lokalizovaný v centru Tampere a současně jako inovační platforma (Uusi Tehdas, 2015). Dochází zde k propojení podnikatelů s lidmi, kteří mohou poskytnout prostory, nástroje, napomáhají spolupráci nebo poskytují mentoring.

Konela představuje „továrnu“, která umožňuje vytváření znalostí z oblasti strojírenství a poskytuje podklady pro jejich následnou komercializaci. Znalosti vznikají v Konele prostřednictvím interdisciplinárního výzkumu a testování demo výrobků, kde jsou do vývojového procesu zapojeny výzkumné organizace, studenti i podniky.

Mediapolis je mezinárodní kampus se zaměřením na média a ICT, který poskytuje prostory pro spolupráci mezi studenty a podnikateli a možnost vytváření mini-klastrů (Mediapolis, 2015).

\section{Perspektivy Jihomoravského kraje}

Jihomoravský kraj je významným centrem výzkumu, vývoje a inovací v České republice. Stejně jako $\mathrm{v}$ př́padě Tampere je inovační aktivita koncentrována především $\mathrm{v}$ hlavním městě, Brně. Jihomoravský kraj má dohromady více než 1 mil. obyvatel, tedy přibližně dvakrát tolik, co region Tampere. Dle hodnocení Evropské komise Regional Innovation Scoreboard patř́ $\mathrm{k}$ mírným inovátorům, avšak v posledních letech zaznamenal masivní rozvoj výzkumné infrastruktury, podnikatelských inkubátorů a vědeckotechnických parků díky své proaktivní inovační politice. Proto jeho inovační výkonnost postupně roste (Evropská komise, 2015).

Celkově se Česká republika v inovační výkonnosti nemůže rovnat Finsku, které je dlouhodobě v pozici inovačního leadera. Tampere má díky tomu před Jihomoravským krajem několikaletý náskok. Zatímco region Tampere usiluje o udržení své pozice jako jednoho z nejvýznamnějších evropských inovátorů, Jihomoravský kraj si teprve svoji pozici buduje. 
Bylo uvedeno, že Region Tampere již má natolik vyspělý inovační systém, že od př́mé podpory inovací přešel $\mathrm{k}$ podpoře nepřímé, tedy $\mathrm{k}$ posilování vztahů mezi aktéry, podpoře transferu znalostí, internacionalizaci atd. Zdá se, že touto cestou by se měl postupně ubírat také Jihomoravský kraj. Jeho inovační infrastruktura již je na velmi dobré úrovni - v Brně funguje několik významných univerzit, které disponují kvalitními výzkumnými kapacitami; Jihomoravské inovační centrum (JIC) založené na partnerství univerzit a veřejné správy zajišt’uje implementaci regionální inovační strategie a vytváŕí mnohé iniciativy pro podporu výzkumu, vývoje a inovací; Jihomoravské centrum pro mezinárodní mobilitu (JCMM) se snaží propagovat kraj jako atraktivní místo pro zahraniční vědce a nadané studenty; funguje zde několik podnikatelských inkubátorů a svá sídla zde mají mnohé významné inovativní firmy; to vše za intenzivní podpory místní veřejné správy (Žítek a Klímová, 2012).

Jestliže chce Jihomoravský kraj následovat cestu regionu Tampere a dosáhnout podobných výsledků, hlavními výzvami do budoucna by mělo být především:

- zaměření na budování vazeb mezi aktéry inovačního systému, tvorba sítě spolupracujících subjektů,

- vyvážení nabídky a poptávky na trhu práce, přizpůsobení oborů vysokoškolského vzdělání potřebám místních průmyslových firem,

- propojení vysokoškolského studia s praxí,

- budování image mezinárodně atraktivního inovačního regionu,

- snaha o navázání kontakti̊ se zahraničními inovačními iniciativami a zahraniční výzkumnou infrastrukturou,

- usnadnění přístupu na zahraniční trhy místním inovativním firmám,

- vysílání místních špičkových vědců do zahraničí za účelem navázání další odborné spolupráce,

- zvážení realizace obdobného komplexního programu, jako je Open Tampere, do kterého by byly zahrnuty nejvýznamnější cíle regionu v oblasti inovační politiky.

Na mnohých z těchto aktivit již Jihomoravský kraj pracuje a region Tampere je pro něj tedy především př́ikladem ukazujícím možný postup, který se osvědčil jako účinný.

\section{Závěr}

Předkládaný př́spěvek analyzuje inovační systém regionu Tampere, jednoho z nejinovativnějších regionů Evropy, s cílem nalézt a popsat prvky tohoto systému, jimiž by se mohl inspirovat Jihomoravský kraj. Jihomoravský kraj si stanovil jako jeden ze svých strategických cílů vyrovnat se evropským inovačním centrům, mezi které Tampere patř́.

Lze konstatovat, že inovační systém regionu Tampere je vyspělý a dynamický, charakteristický četnými vazbami mezi jednotlivými aktéry. Tyto vazby jsou založeny na vzájemné důvěře a dlouhodobé spolupráci a lze je považovat za nejsilnější stránku inovačního systému. Tampere se dle své regionální inovační strategie i dle zvoleného nástrojového mixu snaží tyto vazby udržovat, posilovat a rozšiřovat za hranice regionu i za hranice Finska.

Jihomoravský kraj je centrem výzkumu, vývoje a inovací v České republice. Jeho inovační infrastruktura je na velmi dobré úrovni a hlavním cílem do budoucna je proto dosáhnout potřebného propojení aktérů a jejich motivace ke spolupráci s partnery uvnitř i vně regionu. Se zohledněním regionálních specifik je možné se od Tampere inspirovat $\mathrm{v}$ cílech a oblastech 
podpory regionální inovační strategie či v nástrojovém mixu, ze kterého je nejspíše nejzajímavější iniciativou program Otevřené Tampere.

\section{Poděkování}

Tento článek vznikl v rámci realizace projektu specifického výzkumu Možnosti implementace vybraných veřejných politik v územním rozvoji (MUNI/A/1244/2014).

\section{Literatura}

[1] ALI-YRKKÖ, J. a R. HERMANS, 2002. Nokia in the Finnish innovation system [online]. ETLA Discussion Papers. The Research Institute of the Finnish Economy (811). Dostupné z: www.etla.fi/wp-content/uploads/2012/09/dp811.pdf

[2] ASHEIM, B. T. a A. NAUWELAERS, 2003. Regional Innovation Policy for Small+ Medium Enterprises. Edward Elgar Publishing. ISBN 978-92-79-33164-0.

[3] ASHEIM, B. T. a A. ISAKSEN, 2002. Regional innovation systems: the integration of local 'sticky'and global 'ubiquitous' knowledge. The Journal of Technology Transfer, 27(1), 77-86. ISSN 0892-9912.

[4] BORRÁS, S. a C. EDQUIST, 2013. The choice of innovation policy instruments. Technological Forecasting and Social Change, 80(8), 1513-1522. ISSN 0040-1625.

[5] BOSCHMA, R., 2005. Proximity and innovation: a critical assessment. Regional studies, 39(1), 61-74. ISSN 1360-0591.

[6] COOKE, P., M. GOMEZ URANGA a G. ETXEBARRIA, 1997. Regional innovation systems: Institutional and organisational dimensions. Research policy, 26(4), 475-491. ISSN 0048-7333.

[7] DOLOREUX, D., 2002. What we should know about regional systems of innovation. Technology in society, 24(3), 243-263. ISSN 0160-791X.

[8] DRAHOŠOVÁ, J. a P. BEDNÁř, 2014. Evaluation of Innovations and Innovation Potential of Regions at the NUTS 3 Level. Acta academica karviniensia, 14(1), 32-42. ISSN 1212-415X.

[9] EUROSTAT. Oficiální internetová stránka EU [online]. [vid. 15. prosince 2015]. Dostupné z: ec.europa.eu/eurostat

[10] FINNMEDI. Oficiální internetová stránka FINMEDI [online]. [vid. 15. prosince 2015]. Dostupné z: www.finnmedi.com/in-english/services/

[11] FLANAGAN, K., E. UYARRA a M. LARANJA, 2011. Reconceptualising the 'policy mix'for innovation. Research Policy, 40(5), 702-713. ISSN 0048-7333.

[12] FUCHS, G. a P. SHAPIRA, 2005. Rethinking regional innovation and change: Path dependency or regional breakthrough. 30. Springer Science \& Business Media. ISBN 0387-23001-7

[13] GAŠOVÁ, K., 2015. Nástroje na podporu inovací vevropských regionech. Brno. Diplomová práce. Masarykova univerzita, Ekonomicko-správní fakulta.

[14] HASSINK, R., 2005. How to unlock regional economies from path dependency? From learning region to learning cluster. European Planning Studies, 13(4), 521-535. ISSN 1469-5944.

[15] HERMIA GROUP, 2015. Innovation and product development expert [online]. [vid. 15. prosince 2015]. Dostupné z: www.hermiagroup.fi/in_english/ 
[16] HOWELLS, J., 2005. Innovation and regional economic development: A matter of perspective? Research policy, 34(8), 1220-1234. ISSN 0048-7333.

[17] CHLÁDEK, M., 2014. Regionální inovační strategie - vize 2014 [online]. [vid. 15. prosince 2015]. Dostupné z: www.risjmk.cz/userfiles/file/Region\%C3\%A1ln\%C3\%AD \%20inova\%C4\%8Dn\%C3\%AD\%20strategie\%202014\%20-\%20prezentace.pdf

[18] KAUTONEN, M., 2006. The Regional Innovation Systen Bottom-up: A Finnish Perspective. Tampere. Academic Dissertation. University of Tampere.

[19] KOLEHMAINEN, J., 2002. Territorial Agglomeration as a Local Innovation Environment: The case of a digital media agglomeration in Tampere, Finland. Massachusetts Institute of Technology. Special working paper series on local innovation systems, 25-29.

[20] LARANJA, M., E. UYARRA a K. FLANAGAN, 2008. Policies for science, technology and innovation: Translating rationales into regional policies in a multi-level setting. Research Policy, 37(5), 823-835. ISSN 0048-7333.

[21] LUNDVALL, B. Å., B. JOHNSON, E. S. ANDERSEN a B. DALUM, 2002. National systems of production, innovation and competence building. Research policy, 31(2), 213231. ISSN 0048-7333.

[22] MCCANN, P. a R. ORTEGA-ARGILÉS, 2013. Modern regional innovation policy. Cambridge Journal of Regions, Economy and Society, 6(2), 187-216. ISSN 1752-138.

[23] MEDIAPOLIS. Internetové stránky MEDIAPOLIS [online]. [vid. 15. prosince 2015]. Dostupné z: mediapolis.fi/en/

[24] METCALFE, S. a R. RAMLOGAN, 2008. Innovation systems and the competitive process in developing economies. The Quarterly Review of Economics and Finance, 48(2), 433-446. ISSN 1062-9769.

[25] NEW FACTORY, 2015. About [online]. [vid. 15. prosince 2015]. Dostupné z: newfactory.fi/about

[26] OECD, 2010. Regional innovation strategies [online]. [vid. 15. prosince 2015]. Dostupné z: www.oecd.org/innovation/policyplatform/48137737.pdf

[27] OPEN TAMPERE, 2015. Open Tampere - Minds Wide Open [online]. [vid. 15. prosince 2015]. Dostupné z: www.avointampere.fi/en/the-program/

[28] RALLET, A. a A. TORRE, 1999. Is geographical proximity necessary in the innovation networks in the era of global economy? GeoJournal, 49(4), 373-380. ISSN 1572-9893.

[29] REGIONAL INNOVATION MONITOR PLUS, 2015. West Finland [online]. [vid. 15. prosince 2015]. Dostupné z: ec.europa.eu/growth/tools-databases/regional-innovationmonitor/base-profile/west-finland

[30] SCHIENSTOCK, G., M. KAUTONEN a P. KOSI, 2004. Escaping path dependency. In: P. COOKE, M. HEIDENREICH a H. BRACZYK, eds. Regional innovation systems: the role of governance in a globalized world. 2nd ed. London: Routledge. ISBN 0-41530368-0.

[31] SMITS, R. a S. KUHLMANN, 2004. The rise of systemic instruments in innovation policy. International Journal of Foresight and Innovation Policy, 1(1-2), 4-32. ISSN 1740-2816. 
[32] STATISTICS FINLAND, 2015. Regional Account [online]. [vid. 7. dubna 2015]. Dostupné z: stat.fi/til/abcd_en.html?k=R

[33] STATISTICS FINLAND'S PX-WEB DATABASES, 2016. Establishments by industry and region 2014 [online]. [vid. 15. prosince 2015]. Dostupné z: pxnet2.stat.fi/PXWeb/pxweb/en/StatFin/StatFin__yri_alyr/003_alyr_tau_030.px/?rxid= 25f451aa-c33f-4eb3-baaf-462e2d9474ed

[34] TAMPERE CHAMBER OF COMMERCE AND INDUSTRY, 2015. Economy in the Tampere Region in 2015 [online]. [vid. 7. dubna 2015]. Dostupné z: flcdn.scdn1.secure.raxcdn.com/files/sites/530/economy-in-the-tampere-region-in-2015.pdf

[35] TAMPERE REGION INNOVATION STRATEGY, 2008. The Council of Tampere Region [online]. [vid. 15. prosince 2015]. Dostupné z: Www. pirkanmaa.fi/files/files/hallinto/julkaisut/pdf/iNNOVAATIOSTRATEGIA_ENG.pdf

[36] TAMPERE REGION, 2015. The Council of Tampere Region [online]. [vid. 15. prosince 2015]. Dostupné z: www.pirkanmaa.fi/en/welcome-tampere-region

[37] TAMPERE UNIVERSITY OF APPLIED SCIENCES, 2015. Research \& Development [online]. [vid. 15. prosince 2015]. Dostupné z: www.tamk.fi/web/tamken/researchdevelopment

[38] TAMPERE UNIVERSITY OF TECHNOLOGY, 2015. About TUT [online]. [vid. 15. prosince 2015]. Dostupné z: www.tut.fi/en/about-tut/index.htm

[39] TEKES, 2015. Programmes and Services [online]. [vid. 15. prosince 2015]. Dostupné z: www.tekes.fi/en/programmes-and-services/

[40] TEREDA, 2015. Tereda [online]. [vid. 15. prosince 2015]. Dostupné z: www.tredea.fi/en/tredea/

[41] TÖDTLING, F. a M. TRIPPL, 2005. One size fits all?: Towards a differentiated regional innovation policy approach. Research policy, 34(8), 1203-1219. ISSN 0048-7333.

[42] UNIVERSITY OF TAMPERE, 2015. Oficiální internetová stránka University of Tampere [online]. [vid. 15. prosince 2015]. Dostupné z: www.uta.fi/en/

[43] UYARRA, E., 2010. What is evolutionary about 'regional systems of innovation'? Implications for regional policy. Journal of evolutionary economics, 20(1), 115-137. ISSN 0936-9937.

[44] VTT, 2015. [online] [vid. 15. prosince 2015]. Dostupné z: www.vttresearch.com

[45] WORLD ECONOMIC FORUM, 2015. What's happening to Finland's economy? [online]. [vid. 7. dubna 2015]. Dostupné z: www.weforum.org/agenda/2015/07/whatshappening-to-finland-economy/

[46] YIGITCANLAR, T., A. LÖNNQVIST a H. SALONIUS, 2014. Analysis of a city-region from the knowledge perspective: Tampere, Finland. VINE, 44(3), 445-466. ISSN 03055728 .

[47] ŽÍTEK, V. a V. KLÍMOVÁ, 2012. Regional innovation system in the South Moravian Region. E-Leader online, June 2012. New York: Chinese American Scholars Association. ISSN 1935-4819. 